\title{
Women Empowerment Through Self Help Groups: Realities And Challenges
}

\author{
Mr. Madanant Naik Dr.Anthony Rodrigues \\ Research scholar GOA UNIVERSITY \\ Director, research centre Department of commerce Fr.Agnel College of arts \& commerce
}

\begin{abstract}
This study deals with the understanding of role of Self Help Group (SHG) in Socio-economic development of rural women of the state of Goa. The empowerment of women is vital for the development and growth of the country. Positively motivating women and bringing them into the mainstream of development is a major concern for the Government of India. That was the reason year 2001 was declared as the "Year of women Empowerment" Women's empowerment is critical to the socio economic progress of the community and to bring women into the mainstream of national development has, therefore, been a major concern of the government. The paper specifically focuses on the Socio-economic development of the SHG members and also tries to understand the challenges faced by them
\end{abstract}

Keyword: Microfinance, Self Help Group, Economic Empowerment, Social Empowerment

\section{INTRODUCTION:}

The development and growth of the Microfinance sector have been tremendous and eye-catching over the past few decades. Microfinance through SHG has become a medium of making formal banking services to the people from remote areas. A Self Help Group (SHG) is mostly a village - based financial organization usually composed of 10 - 20 local women. SHG agrees to save on a regular basis and convert their savings into a common fund known as 'group corpus'. The model has grown at a very rapid speed and has gained attention as a very innovative way of delivering microfinance services to the poor and the needy people, who find it extremely difficult to reach the and gain access to formal banking services. By integrating their personal savings into a single deposit, SHG minimizes the SHG bank's transaction costs and create an attractive amount of deposits. Through SHG, banks can provide formal financial services to small rural depositors while paying them a market interest rate. SHG is started by nonprofit organizations and also by Government organizations that generally have broad poverty reduction agendas. SHG is seen as instruments for a variety of goals, including giving control to women, increasing management ability among adverse people, increasing school enrollments, and improving diet and the use of family planning measures. SHG proves to be effective tools for poverty reductions and Capacity building of rural natives. It provides women an opportunity to become socially and economically self-sufficient. SHG provides them freedom express their views, feelings about the various societal and political concerns. SHG also helps to create knowledge among its members about social evils, the rights of women, about the laws and regulations of government in general. The empowerment of women is vital for the economic development of a nation and also plays a key role in building a base for societal change. To improve the socio-economic conditions of the population of any country, it has become a prerequisite to empower women by enhancing and making certain their role to the optimal level. The development strategies could no longer achieve their targeted goal if it neglects the need for contribution and participation of women to the social activities. It's only when women are considered as equal partners in progress with men, overall development and harmonious development of any country would be attainable. Thus, the liberation of women is a precondition for the nation's economic development and social upliftment and if equal economic and social opportunities for women are not provided, emancipation cannot really happen. Bringing women into the mainstream of development is one of the major challenges for developing countries like India.

Self Help Groups (SHGs): A Self-Help Group is a group of people from the same socio-economic background up to 20 members. These groups are promoted by Government agencies or NGOs with the aim of solving the common problems of group members either financial or social through mutual help.

Features of Self Help Groups:

- $\quad$ SHGs are well accepted and established by the government or NGOs .

- They can open accounts in the bank in its own name, receive government grants and funds for various expansion activities. 
- They perform various activities as social intermediaries and often involved in numerous social activities.

- They keep their own books of accounts. It is a structured body, including electives, Group President, Secretary, and Treasurer.

- They have the self-governing body. SHGs activate small saving and rotate it in a group.

\section{REVIEW OF LITERATURE:}

(Saroj \& Singh, November (2015)): The paper intends to study the role of micro-finance through Self Help Groups (SHGs) in the socioeconomic empowerment of women. The study has been carried out in Ajmer district of Rajasthan covering a sample containing 75 beneficiaries, 4 villages, 8 SHGs and 2 blocks. The study concludes that Socio-economic empowerment has been considered significant for overall development. Women's empowerment is evidently necessary for escalating socio-economic condition of the women in the society. The SHGs enabled women to aware about their rights, entitlements, taking part in various development programs and economic activities for their substantial development. Thus, SHGs made a noteworthy impact on women empowerment.

(Baghel \& Shrivastava, November (2015)):This study deals with the understanding of the impact of Self-Help Group (SHG) on the overall socioeconomic development of rural women of Durg district of Chhattisgarh. The study considered four independent variables Individual Social Indicators, Community Social Indicators, Individual Economic Indicators and Community Economic Indicators to analyze the socioeconomic development of rural women. The study indicates that economic and social indicators have significant positive impact on Socio-economic Development of rural women of Durg. The background of ${ }^{\text {ee }}$ social respect and communication of Individual Social Indicators have a significant impact on Development of women of Durg district of Chhattisgarh.

(Shettar, (Apr. 2015)): This paper makes an attempt to analyze the position of Women Empowerment in India and highlights the Issues and Challenges of Women Empowerment. The study is based on purely from secondary sources. The study reveals that women of India are relatively disempowered and they enjoy a somewhat lower status than that of men in spite of many efforts undertaken by the Government. The study shows that acceptance of biased gender norms by women is still prevailing in the society. The study concludes with a remark that, access to Employment, Education, and Change in Social Structure are only the enabling factors to Women Empowerment.

\section{STATEMENT OF THE PROBLEM}

Economic development of a country means that the per capita income of that country moves increases. Similar to any other country of the world, India has been endowed with natural and human resources who need appropriate utilization by adopting recent technology for growth and development of the economy. The empowerment of women is crucial for the development of the country. Empowerment is about the extent of rearrangement of power relations between men and women to bring a structural transformation in the society. In India, where population maintains an equal ratio of males with females, The appearance of women entrepreneurs have great importance or else it will be amounting to neglecting 50 per cent of the entrepreneurial ability of the country. Therefore, it would be worthwhile to reflect on the potentialities of SHGs in bringing such structural transformation. The study is an attempt to provide a holistic view of empowerment, taking place through SHGs in the lives of women in the state of Goa.

\section{OBJECTIVES OF THE STUDY}

The proposed study is intended to carry out the following objectives in view: 1. To assess the effectiveness of Self-help groups in the economic empowerment of women.

2. To assess the social empowerment of SHGs due to microfinance intervention.

3. To study the present and future Challenges and make a suitable suggestion for Women SHG.

\section{HYPOTHESIS}

On the bases of above objectives the following hypothesis is formulated.

$\mathrm{H}_{0}$ : There is no improvement in the economic empowerment index of women through SHGs.

$\mathrm{H}_{0}$ : There is no significant improvement in the overall Social empowerment of SHG Members after joining the microfinance program.

\section{METHODOLOGY}

The study is analytical and descriptive in nature. The total universe of the study includes all the beneficiaries of SHGs in North and South Goa districts. Both primary data and secondary data were used for the study purpose. Primary data are collected through the interview schedule to the selected beneficiaries. Secondary data essential for the study are collected from books, journals and other periodicals and reports of the Government and other agencies.

\section{SAMPLING DESIGN}

There are 6 talukas in North Goa District and 6 Talukas in South Goa district. Out of 6 Talukas in North Goa district and 6 Talukas in South 2 are randomly selected from each Taluka and out of the selected 
Talukas, 40 SHGs are randomly selected and from each SHG 5 members interviewed. Thus a total number of 200 SHG members are taken from both North Goa and South Goa district for the study.

\section{SCOPE OF THE STUDY}

The present study covers only the SHG members in North Goa and South Goa district. It is confined to demographic aspects of the sample respondents and the empowerment of women in the study area.

\section{TOOLS OF DATA COLLECTION}

Both primary and secondary data are used for the study, the primary data were collected by using a structured interview schedule and the secondary data was collected from various publications of both central and state governments and NABARD.

\section{ANALYSIS OF DATA}

The data were analyzed and interpreted by using diverse statistical tools.

Economic Empowerment Index: Economic empowerment is the capacity of women and men to participate in, benefit from and contribute to growth processes in a way that recognizes the value of their contributions, respect their dignity and make it promising to negotiate a fairer distribution of the benefits of growth. Economic empowerment increases access of women's to economic resources and new opportunities including jobs, financial services, property and other productive resources, skill development and other market information. Women economic empowerment is a prerequisite for sustainable development and for achieving the Development Goals. And economic empowerment is also a right. Women's economic empowerment takes public policies, a holistic approach and long-term commitment from all development actors. Donors can also increase their investment.

For the purpose of the study, the economic empowerment index is rating score of economic parameters measured in terms of household assets, household income, household expenditure, household savings, loan and housing type of the SHG members. Scores were assigned to different Economic Indicators for the preparing Economic Index shown in table 1.

Table 1: Score of Economic Empowerment Index

\begin{tabular}{|l|l|l|l|l|l|l|l|}
\hline $\begin{array}{l}\text { Economic } \\
\text { Indicators/ } \\
\text { Scores }\end{array}$ & 1 & 2 & 3 & 4 & 5 & 6 & $\begin{array}{l}\text { Max } \\
\text { Score }\end{array}$ \\
\hline $\begin{array}{l}\text { Household } \\
\text { Assets }\end{array}$ & Below 5000 & 10000 & 15000 & 20000 & 25000 & $\begin{array}{l}\text { Above } \\
25000\end{array}$ & 6 \\
\hline $\begin{array}{l}\text { Household } \\
\text { Income }\end{array}$ & Below 5000 & 10000 & 15000 & 20000 & 25000 & $\begin{array}{l}\text { Above } \\
25000\end{array}$ & 6 \\
\hline $\begin{array}{l}\text { Expenditure } \\
\text { Savings }\end{array}$ & Below 5000 & 8000 & 11000 & 14000 & 17000 & $\begin{array}{l}\text { Above } \\
17000\end{array}$ & 6 \\
\hline $\begin{array}{l}\text { Loan } \\
\text { Below 200 }\end{array}$ & 400 & 600 & 800 & 1000 & $\begin{array}{l}\text { Above } \\
1000\end{array}$ & 6 \\
\hline $\begin{array}{l}\text { Housing } \\
\text { Type }\end{array}$ & $\begin{array}{l}\text { Katcha } \\
\text { house(Rented) }\end{array}$ & $\begin{array}{l}\text { Katcha } \\
\text { House } \\
\text { (Own) }\end{array}$ & $\begin{array}{l}\text { Semipucca } \\
\text { House } \\
\text { (Rent) }\end{array}$ & $\begin{array}{l}\text { Semipucca } \\
\text { House } \\
\text { (Own) }\end{array}$ & $\begin{array}{l}\text { Pucca } \\
\text { House } \\
\text { (Rent) }\end{array}$ & $\begin{array}{l}\text { Pucca } \\
\text { House } \\
\text { (Owned) }\end{array}$ & 6 \\
\hline TOTAL SCORE & 6000 & 8000 & 10000 & $\begin{array}{l}\text { Above } \\
10000\end{array}$ & 6 \\
\hline
\end{tabular}

Source: primary Data

Economic Empowerment Index: It is calculated by using the following expression,

Economic Index $(\mathrm{En})=\_$Ei / _Ei $(\max )$

Where,

Ei $=$ ith Economic Indicators

_Ei $(\max )=$ Maximum scores ith Economic Indicators

Economic empowerment Index for 200 selected SHG members is calculated from the data of the situations before and after joining the SHGs. The study revealed that the average economic empower index increased before joining the microfinance from 18.98 percent to 23.46 percent showing improvement in the economic status of the most of the sample SHG members.

Table 2: Average Economic Empowerment (EE) Index

\begin{tabular}{|l|l|l|l|l|l|l|l|}
\hline & N & Range & Min. & Max. & Mean & $\begin{array}{l}\text { Std. } \\
\text { Deviation }\end{array}$ & $\begin{array}{l}\text { Std. } \\
\text { Error }\end{array}$ \\
\hline $\begin{array}{l}\text { Before } \\
\text { Joining }\end{array}$ & 200 & 13.03 & 13.14 & 26.17 & 18.98 & 3.10 & 0.23 \\
\hline
\end{tabular}




\begin{tabular}{|l|l|l|l|l|l|l|l|}
\hline SHG & & & & & & & \\
\hline $\begin{array}{l}\text { After } \\
\text { Joining } \\
\text { SHG }\end{array}$ & 200 & 12.11 & 16.07 & 28.17 & 23.46 & 2.85 & 0.20 \\
\hline
\end{tabular}

Source: primary Data

Hypothesis testing is carried out to examine the significant impact on the economic empowerment index by comparing before and after situation. The result of the hypothesis testing is presented in table 3 and table 4.

Hypothesis testing:

Null hypothesis $\left(\mathrm{H}_{0}\right)$ : There is no significant improvement in the overall economic empowerment index of MFI's SHG Members after joining the microfinance program.

\begin{tabular}{|l|l|l|l|l|l|}
\hline \multicolumn{2}{|c|}{ Table 3:Paired Samples Statistics } \\
\hline \multicolumn{2}{|c|}{} & Mean & N & Std. Deviation & $\begin{array}{l}\text { Std. Error } \\
\text { Mean }\end{array}$ \\
\hline \multirow{2}{*}{ Pair 1 } & After & 23.34 & 200 & 2.840 & .201 \\
\cline { 2 - 7 } & Before & 18.86 & 200 & 3.087 & .218 \\
\hline
\end{tabular}

Source: primary Data

\begin{tabular}{|c|c|c|c|c|c|c|c|c|}
\hline \multicolumn{9}{|c|}{ Table 4:Paired Samples Test } \\
\hline \multirow{3}{*}{$\begin{array}{l}\text { Economic } \\
\text { Empowerm } \\
\text { ent Index of } \\
\text { SHG } \\
\text { Member }\end{array}$} & \multicolumn{5}{|c|}{ Paired Differences } & \multirow[t]{3}{*}{$\mathrm{t}$} & \multirow[t]{3}{*}{ df } & \multirow{3}{*}{$\begin{array}{l}\text { Sig. } \\
(2- \\
\text { taile } \\
\text { d) }\end{array}$} \\
\hline & \multirow[t]{2}{*}{$\begin{array}{l}\text { Mea } \\
\mathrm{n}\end{array}$} & \multirow[t]{2}{*}{$\begin{array}{l}\text { Std. } \\
\text { Deviatio } \\
n\end{array}$} & \multirow[t]{2}{*}{$\begin{array}{l}\text { Std. } \\
\text { Error } \\
\text { Mean }\end{array}$} & $\begin{array}{l}99 \% \\
\text { Interva } \\
\text { Differe }\end{array}$ & $\begin{array}{l}\text { Confidence } \\
\text { of the }\end{array}$ & & & \\
\hline & & & & Lower & Upper & & & \\
\hline $\begin{array}{l}\text { After } \\
- \\
\text { Befor } \\
\text { e }\end{array}$ & $\begin{array}{l}4.48 \\
0\end{array}$ & 1.007 & .071 & 4.295 & 4.665 & $\begin{array}{l}62.8 \\
97\end{array}$ & $\begin{array}{l}19 \\
9\end{array}$ & $\begin{array}{l}.000 \\
*\end{array}$ \\
\hline
\end{tabular}

Source: primary Data

Since $\mathrm{t}$ value is significant at $\mathrm{a}=0.01$ level, the above null hypothesis (H0) is rejected and the alternative hypothesis is accepted. Thus, it can be concluded that there is a significant improvement in the overall economic empowerment index of SHG members after joining the microfinance program. The study also revealed that the SHG members have now been trying very hard to find new and innovative business ideas. The Local government bodies are playing a key role in promoting the SHG to take up entrepreneurial activities. There is government as well as NGO who provides training and other services for the groups for their upliftment. The only problem faced by the groups is with regards to the marketing of their products.

Assessment of Social Empowerment Index: Social empowerment is understood as the process of developing a sense of autonomy and confidence, and acting independently and collectively to change social relationships and fight against the institutions and discourse that exclude poor people and keep them in extreme poverty. Poor people's empowerment, and their ability to hold others responsible, is influenced by their personal assets (such as land, housing, livestock, savings) and capabilities of all types: human being (such as good wellbeing and education), social (such as social belonging, leadership relations, and a sense of identity) and psychological (self-confidence, self-esteem, the ability to imagine and aspire to a better future). Also important are people's combined assets and abilities, such as voice, organization, representation, and identity.

Scores assigned to different Social Indicators for preparing Social Index shown in table 5.

Table 5: Scores for Social Empowerment Index

\begin{tabular}{|l|l|l|l|l|l|l|l|}
\hline $\begin{array}{l}\text { Social } \\
\text { Indicators/Scores }\end{array}$ & 1 & 2 & 3 & 4 & 5 & $\begin{array}{l}\text { Max } \\
\text { Score }\end{array}$ \\
\hline Self Confidence & $\begin{array}{l}\text { Confidence of } \\
\text { facing } \\
\text { financial crisis }\end{array}$ & Not at all & $\begin{array}{l}\text { Very } \\
\text { little }\end{array}$ & Somewhat & Much more & $\begin{array}{l}\text { To a } \\
\text { great } \\
\text { extent }\end{array}$ & 5 \\
\hline $\begin{array}{l}\text { Confidence of } \\
\text { meeting }\end{array}$ & Not at all & $\begin{array}{l}\text { Very } \\
\text { little }\end{array}$ & Somewhat & Much more & $\begin{array}{l}\text { To a } \\
\text { great }\end{array}$ & 5 \\
\hline
\end{tabular}


Women Empowerment Through Self Help Groups: Realities And Challenges

\begin{tabular}{|c|c|c|c|c|c|c|}
\hline official people & & & & & extent & \\
\hline $\begin{array}{l}\text { Physical } \\
\text { mobility }\end{array}$ & $\begin{array}{l}\text { No } \\
\text { Mobility }\end{array}$ & $\begin{array}{l}\text { Seldom/ } \\
\text { Restricted }\end{array}$ & $\begin{array}{l}\text { Sometimes/ } \\
\text { Occasional }\end{array}$ & More/Often & $\begin{array}{l}\text { Free and } \\
\text { always }\end{array}$ & 5 \\
\hline \multicolumn{7}{|l|}{ Skills } \\
\hline $\begin{array}{l}\text { Communication } \\
\text { skills }\end{array}$ & $\begin{array}{l}\text { Hesitates } \\
\text { to } \\
\text { talk }\end{array}$ & $\begin{array}{l}\text { Talk only } \\
\text { if } \\
\text { asked }\end{array}$ & $\begin{array}{l}\text { Sometimes } \\
\text { talks }\end{array}$ & $\begin{array}{l}\text { Normally } \\
\text { /usually } \\
\text { talks }\end{array}$ & $\begin{array}{l}\text { Freely } \\
\text { and } \\
\text { openly } \\
\text { talks }\end{array}$ & 5 \\
\hline Business Skills & $\begin{array}{l}\text { Extremely } \\
\text { Poor }\end{array}$ & Poor & Satisfactory & Good & Excellent & 5 \\
\hline $\begin{array}{l}\text { Financial Skills } \\
\text { (book } \\
\text { keeping, } \\
\text { accounting, etc) }\end{array}$ & $\begin{array}{l}\text { Extremely } \\
\text { Poor }\end{array}$ & Poor & Satisfactory & Good & Excellent & 5 \\
\hline \multicolumn{7}{|c|}{ Social awareness and recognition } \\
\hline $\begin{array}{l}\text { Social } \\
\text { recognition }\end{array}$ & Not at all & $\begin{array}{l}\text { Very } \\
\text { Little }\end{array}$ & Somewhat & Much more & $\begin{array}{ll}\text { To a } \\
\text { great } \\
\text { Extent }\end{array}$ & 5 \\
\hline $\begin{array}{l}\text { Social awareness } \\
\text { (AIDS, family } \\
\text { planning, } \\
\text { Government } \\
\text { schemes } \\
\text { Etc) }\end{array}$ & Not at all & $\begin{array}{l}\text { Very } \\
\text { Little }\end{array}$ & Somewhat & Much more & $\begin{array}{ll}\text { To a } \\
\text { great } \\
\text { Extent }\end{array}$ & 5 \\
\hline $\begin{array}{l}\text { Ability to take } \\
\text { up } \\
\text { Social issues like } \\
\text { abuse, } \\
\text { Violence, drugs, } \\
\text { Alcoholism etc) }\end{array}$ & $\begin{array}{l}\text { Submit to } \\
\text { Oneself }\end{array}$ & Resist & $\begin{array}{l}\text { Lodge } \\
\text { Complain } \\
\text { in } \\
\text { The group }\end{array}$ & $\begin{array}{l}\text { Complain } \\
\text { to } \\
\text { Relatives }\end{array}$ & Warns & 5 \\
\hline $\begin{array}{l}\text { Respect in the } \\
\text { family }\end{array}$ & Not at all & $\begin{array}{l}\text { Very } \\
\text { Little }\end{array}$ & Somewhat & Much more & $\begin{array}{ll}\text { To a } \\
\text { great } \\
\text { Extent }\end{array}$ & 5 \\
\hline \multicolumn{7}{|c|}{ Access to facilities/services } \\
\hline $\begin{array}{l}\text { Medical } \\
\text { facilities }\end{array}$ & $\begin{array}{l}\text { Extremely } \\
\text { Poor }\end{array}$ & Poor & Satisfactory & Good & Excellent & 5 \\
\hline $\begin{array}{l}\text { Hygienic } \\
\text { sanitation } \\
\text { Facilities } \\
\end{array}$ & $\begin{array}{l}\text { Extremely } \\
\text { Poor }\end{array}$ & Poor & Satisfactory & Good & Excellent & 5 \\
\hline $\begin{array}{l}\text { Drinking water } \\
\text { supply }\end{array}$ & $\begin{array}{l}\text { Extremely } \\
\text { Poor }\end{array}$ & Poor & Satisfactory & Good & Excellent & 5 \\
\hline \multicolumn{6}{|l|}{ TOTAL SCORE } & 65 \\
\hline
\end{tabular}

Source: primary Data

Social Empowerment Index: It is calculated by using the following expression

Social Index $(\mathrm{Sn})=.\_\mathrm{Si} /$ Si $(\max )$

Where,

_Si $=$ ith Social Indicators

_Si $(\max )=$ Maximum scores ith Social Indicators Social empowerment Index for 200 SHG members is calculated from the data of the situations before and after joining the SHGs. It is found that the average social empowerment index increased from 26.53 per cent to 47.64 per cent after joining the microfinance program.

Table 6: Average Social Empowerment Index

\begin{tabular}{|l|l|l|l|l|l|l|l|}
\hline & N & Range & Min. & Max. & Mean & $\begin{array}{l}\text { Std. } \\
\text { Deviation }\end{array}$ & $\begin{array}{l}\text { Std. } \\
\text { Error }\end{array}$ \\
\hline $\begin{array}{l}\text { Before } \\
\text { Joining } \\
\text { SHG }\end{array}$ & 200 & 37 & 12.02 & 49.02 & 26.53 & 7.86 & 0.56 \\
\hline $\begin{array}{l}\text { After } \\
\text { Joining } \\
\text { SHG }\end{array}$ & 200 & 33.06 & 27.02 & 60.08 & 47.64 & 6.49 & 0.46 \\
\hline
\end{tabular}


Source: primary Data

Further, it is observed that there is some improvement in the social empowerment index after joining the microfinance program. Paired samples t-test is used to test the hypothesis for establishing the impact on the social Empowerment index of SHG members after joining the microfinance program. The result of hypothesis testing is shown in table 8 and table 9.

Hypothesis testing:

Null hypothesis $\left(\mathrm{H}_{0}\right)$ : There is no significant improvement in the overall Social empowerment of SHG Members after joining the microfinance program.

\begin{tabular}{|l|l|l|l|l|l|}
\hline \multicolumn{2}{|l|}{ Table 7:Paired Samples Statistics } & Mean & N & Std. Deviation & $\begin{array}{l}\text { Std. } \\
\text { Mean }\end{array}$ \\
\hline \multirow{2}{|l|}{} & $\begin{array}{l}\text { EMPOWERMENT } \\
\text { INDEX(After) }\end{array}$ & 47.58 & 200 & 6.483 & .458 \\
\cline { 2 - 6 } & $\begin{array}{l}\text { EMPOWERMENT } \\
\text { INDEX(Before) }\end{array}$ & 26.50 & 200 & 7.855 & .555 \\
\hline
\end{tabular}

\begin{tabular}{|c|c|c|c|c|c|c|c|c|}
\hline \multicolumn{9}{|c|}{ Source: primary Data } \\
\hline \multicolumn{9}{|c|}{ Table 8:Paired Samples Test } \\
\hline & \multicolumn{5}{|c|}{ Paired Differences } & \multirow[t]{3}{*}{$\mathrm{t}$} & \multirow[t]{3}{*}{$\mathrm{df}$} & \multirow{3}{*}{$\begin{array}{l}\text { Sig. } \\
(2- \\
\text { tailed } \\
)\end{array}$} \\
\hline & \multirow[t]{2}{*}{$\begin{array}{l}\mathrm{Me} \\
\text { an }\end{array}$} & \multirow[t]{2}{*}{$\begin{array}{l}\text { Std. } \\
\text { Deviat } \\
\text { ion }\end{array}$} & \multirow{2}{*}{$\begin{array}{l}\text { Std. } \\
\text { Error } \\
\text { Mea } \\
\mathrm{n}\end{array}$} & \multicolumn{2}{|c|}{$\begin{array}{l}99 \% \text { Confidence } \\
\text { Interval of the } \\
\text { Difference }\end{array}$} & & & \\
\hline & & & & $\begin{array}{l}\text { Lowe } \\
\mathrm{r}\end{array}$ & Upper & & & \\
\hline $\begin{array}{l}\text { EMPOWE } \\
\text { RMENT } \\
\text { INDEX(Aft } \\
\text { er) } \\
\text { EMPOWE } \\
\text { RMENT } \\
\text { INDEX(Be } \\
\text { fore) }\end{array}$ & $\begin{array}{l}21 . \\
085\end{array}$ & 8.330 & .589 & $\begin{array}{l}19.55 \\
3\end{array}$ & 22.617 & $\begin{array}{l}35 . \\
798\end{array}$ & $\begin{array}{l}1 \\
9 \\
9\end{array}$ & $.000^{*}$ \\
\hline
\end{tabular}

Source: primary Data

Since $\mathrm{t}$ value is found significant at $\mathrm{a}=0.01$, the above null hypothesis is rejected and the alternative hypothesis is accepted. Therefore, it can be said that there is a significant improvement in the overall social empowerment index of SHG members after joining the microfinance program. The survey revealed that most of the groups practice rotation among the committee members, which give equal opportunities to each member to be a part of the committee. This creates a kind of confidence since now they get an opportunity to interact with the outside world. They have now gained knowledge with regards to various health and sanitation related issues through various talks and seminars. The only reason which pulls them back is the literacy level. But with proper training and consultations, they have managed to overcome education hurdle.

\section{The Present and Future Challenges and For Women SHG}

SHGs have achieved remarkable success in empowering rural masses, especially rural women, both socially and economically. The government has been encouraging the micro-finance based model of poverty reduction. E.g. (NRLM) National Rural Livelihood Mission However, the prevailing model of SHG microfinance and women SHGs, continue to face a myriad of problems. No doubt that the model has successfully inculcated financial training and discipline among the rural poor, more needs to be done to make this model a true harbinger of prosperity at the grass-roots level. The set-up of SHG Federations and launch of MUDRA Bank may prove to be a boon for these SHGs. The Women SHG has been playing a major role in both economic and social empowerment of women. They were primarily created to induce poor people to make small savings and to help in mutual aid by accessing banks and public services.

Major Problems Faced Are Listed Below:

- Recognition of women as an important and potential member in financially supporting her family during crisis situations reflects empowerment at family level.

- Gender bias was widely prevalent in the village. A girl child was usually not preferred and looked as a burden and they were married immediately after they attain puberty. 
- Ignorance of Members/Participants: Even though the authorities take measures for creating awareness among the group members about the varied schemes valuable to them, still the majority of the groups are unaware of the schemes of assistance accessible to them. Several are Ignorant about the scheme.

- Inadequate Training Facilities: The training services given to the SHGs members in the specific areas of product selection, quality of products, managerial ability, production techniques, and packing, other technical knowledge are not adequate to compete with that of strong units.

- Problems Related to Finance: Women have little financial independence at home. Therefore, women SHGs often fail to augment their collateral corpus adequately. This makes banks reluctant to finance project lead by such SHGs.

- Problems of Marketing: Marketing is an important area of functioning of the SHGs. However, they face numerous problems in the marketing of items produced by them. Following are the major problems relating to marketing.

$>$ Lack of a sufficient number of orders.

$>$ No linkage with any the marketing agencies.

$>$ Lack of adequate sales promotion measures.

$>$ Lack of permanent marketplace for the produce of SHGs.

$>$ Inability to create a proper brand name.

$>$ Poor/unattractive packing system.

$>$ Low quality of produce due to the application of conventional technology, resulting in a poor market,

$>$ Tough competition from other established suppliers.

$>$ Lack of a distinct and well-knit channel of distribution for marketing.

- Lack of Stability and Unity Especially among women SHGs: Enormous workload of women, especially on account of their family obligations, leads to poor productivity of women member of SHGs. In the case of SHGs dominated by women, it is found that there is no permanence of the groups as; many married women are not in a position to associate with the group due to the change of their place of residence. In addition to it, there is no unity among women members owing to personal reasons.

- Exploitation by Strong Members: It is also observed that in the case of many SHGs, strong members try to earn a lion's share of the revenue of the group, by exploiting the ignorant and illiterate members. This may lead to the isolation of the actual beneficiaries.

- Weak Financial Management: Model hardly focuses on investment perspective and development of skill level of the borrower, and the funds diverted for other personal and domestic purposes like marriage, construction of house etc. making credit available is not a panacea to rural problems.

- Low Return: The return on savings is not attractive in certain groups due to incompetent management, the high cost of production, an absence of quality consciousness etc.

- Affinity: The SHGs are formed, more often, to complete targets set by the government agency and NGO, which grossly lack affinity, the most important factor. This also leads to Lack of proper direction and professionalism about the proper routing of the funds. A need-based credit is not accessible rather an equal division of funds among the women leads to the improper utilization of funds. There is a need to focus on differential credit.

- Because of emphasis of govt. On mostly opening bank accounts and financial inclusion, tapping the entrepreneurial energy has been left to the SHG. Thus, the innovative ways of financing are lacking. This also leads to conservative attitude amongst the women, which is not so good for any expansion of the business. The rigidity of the structure is a major weakness. A need-based credit is not available rather an equal division of funds among the women leads to the improper utilization of funds. There is a need to focus on differential credit. Because of importance is given by the govt. On mostly opening new bank accounts and financial inclusion, good for tapping the entrepreneurial opportunity has been left to the groups. Still innovative ways of providing formal financial services to the unreached poor are lacking. This also leads to conservative approach among the women, which is good for any business expansion.

\section{Suggestions for Women empowerment through SHG}

1. In order to solve the various problems and issues relating to the marketing of SHGs products, the state level authorities should expand the activities throughout the state instead of being limiting its operations in a particular area.

2. Various SHGs functioning in a particular Panchayat area can form a co-operative society. This cooperative society may be assigned with the job of marketing the products of different SHGs under a common brand name. Additionally, the society can also undertake some sales promotional activities and acquire rare inputs for the benefits of member SHGs. 
3. Non-Government Organizations (NGOs) can play an important role towards empowering of women entrepreneurs by providing them basic education, motivational training, and financial help and so on.

4. All the members in the SHGs may not have the same knowledge and proficiency. NGOs should spot the incompetent members of the SHG and impart appropriate training to them in order to improve their competency. And for this purpose, short term guidance programs can be organized at the panchayat level.

5. Frequent awareness camps can be organized by the Rural Development Authorities (RDA) to make awareness about the different schemes of assistance accessible to the participants in the SHGs.

6. Lastly, arrangements may be made by the financial institutions/Banks for providing ample financial assistance to the SHGs strictly on the basis of their genuine performance without any kind of favoritism of caste, politics etc.

7. Measures should be taken to attract more and more people, especially the illiterate and the poorest section of the rural people to become members of SHG's.

8. Small responsible tasks and jobs to be done on behalf of the government can be entrusted to SHGs thus helping them to earn additional income.

9. In order to enhance the thrift of the SHG members attractive savings and insurance schemes can be introduced.

In the emerging changes in the values and attitudes of the members of the SHGs is a clear manifestation of socio-economic empowerment intervention yielding comparatively quicker results. The socio-economic programs reinforce each other and promote all-round development of the children, the women, the households and the society.

\section{CONCLUSION:}

The participation of women in SHGs has enriched their income, savings, and empowerment. The involvement of the women in the group considerably contributes to improvement AND perfection in the quality of life, social status and confidence of the members, the SHG in the study area are taking the lead and playing an important role in social transformation, infrastructure building, and welfare activities. Self Help Group scheme is one of the significant schemes through which empowerment of women, in terms of better leadership, decision making, utility, and skill up gradation. Considering the huge number of poor discriminated and deprived women there is need to encourage the women to become entrepreneurs on their own. The agenda of women SHG should be to work towards the empowerment of the members and also other underprivileged poor women in the society. One such institution is EDUCATION which will not only help in breaking the mold of ignorance of rural women but is the right path to women social development and empowerment.

\section{BIBLIOGRAPHY}

[1] Baghel, D., \& Shrivastava, D. (November (2015)). Role Of Self Help Groups In Socio-Economic Development Of Rural Women: A Study On Durg District Of Chhattisgarh. Excel International Journal Of Multidisciplinary Management Studiesvol.5 (11) , 1-23.

[2] Chepchirchir, S. C. ( August 2013). Impact Of Women Participation In Self-Help Groups On Self Economic Empowerment In Nakuru County. Interdisciplinary Journal Of Contemporary Research In Businessvol 5, No $4,382-405$.

[3] Das, S. K., \& Bhowal, P. A. (2013). Self Help Groups - An Empowerment Model Or Financial Model:Perceptions Of Stakeholders. European Journal Of Business And Management Vol.5, No.29, , 170-190.

[4] Kumar Das, S. D., \& Boruah, S. D. Micro Finance Through Self Help Groups (Shgs): A Tool For SocioEconomic Development Of Rural Assam (A Case Study Of Lakhimpur And Dhemaji District).

[5] Reji, D. ( March (2013)). Economic Empowerment Of Women Throuh Self Help Groups In Kerala. International Journal Of Marketing, Financial Services \& Management Researchvol.2, No. 3 , 97-113.

[6] Saroj, L., \& Singh, C. S. (November (2015)). Women Empowerment Through Microfinance (Shgs): A Study Of Ajmer. International Research Journal Of Social Sciencesvol. 4(11), 1-6.

[7] Shettar, D. (. ((Apr. 2015)). A Study On Issues And Challenges Of Women Empowerment In India. Iosr Journal Of Business And Management (Iosr-Jbm)Volume 17, Issue 4.Ver. I , 13-19.

[8] Singh, D. H., \& Singh, D. N. An Impact Assessment Of Microfinance: A Case Study Of Socio-Economic Empowerment Of Shg Members In Manipur (India).

[9] Singh, R. (October 2012, ). Women Entrepreneurship Issues, Challenges And Empowerment Through Self Help Groups: An Overview Of Himachal Pradesh. International Journal Of Democratic And Development Studies (Ijdds), Vol. 1, No. 1, , 45-58.

[10] Umamaheswari, P., Gurusamy, M., \& Jayakumar, D. A. ( March (2013)). A Study On Social Impact Of Women Self Help Groups In Mettur Taluk, Salem District, Tamilnadu. International Journal Of Social Science \& Interdisciplinary Research Ijssir, Vol. 2 (3), , 1-16. 
